\title{
Analgesic effect of silymarin in chicks
}

\author{
A.S. Naser* and Y.M. Amin \\ Department of Physiology, Biochemistry \& Pharmacology, College of Veterinary Medicine, University of Mosul, Mosul, Iraq \\ *email: ahmedvet81@yahoo.com
}

(Received August 18, 2018; Accepted December 21, 2018)

\begin{abstract}
There were no studies about the analgesic effect of silymarin in the chicken. This study examined antinociceptive effect of silymarin given intraperitonially in 7-9 day-old chicks. The median effective dose of silymarin for the induction of analgesia to electric stimulation in the chicks was $65.3 \mathrm{mg} / \mathrm{kg}$. Silymarin at 60,120 and $240 \mathrm{mg} / \mathrm{kg}$ revealed analgesic effect to electric stimulation in chicks in dose dependent manner in comparison with the control group. The analgesic effect of silymarin at 120 and $240 \mathrm{mg} / \mathrm{kg}$ started at $15 \mathrm{~min}$ after injection and lasted after over $120 \mathrm{~min}$ of injection were as silymarin at $60 \mathrm{mg} / \mathrm{kg}$ the analgesic effect started at $15 \mathrm{~min}$ after injection and declined before $120 \mathrm{~min}$ of injection. The peak of analgesic effect for 60 , 120 and $240 \mathrm{mg} / \mathrm{kg}$ were at $60 \mathrm{~min}$ after injection. These results indicate that silymarin have an analgesic property in the chicks model.
\end{abstract}

Keywords: Silymarin, Analgesia, Chicks, Electrostimulation Available online at http://www.vetmedmosul.com

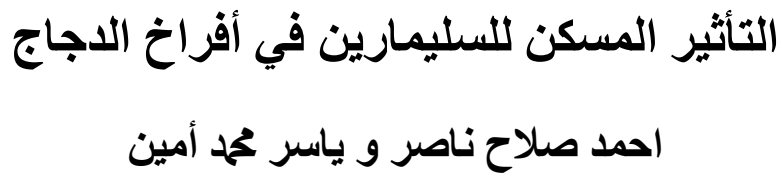

$$
\text { فرع الفسلجة و الكيمياء الحياتية والأدوية، كلية الطب البيطري، جامعة الموصل، الموصل، العراق }
$$

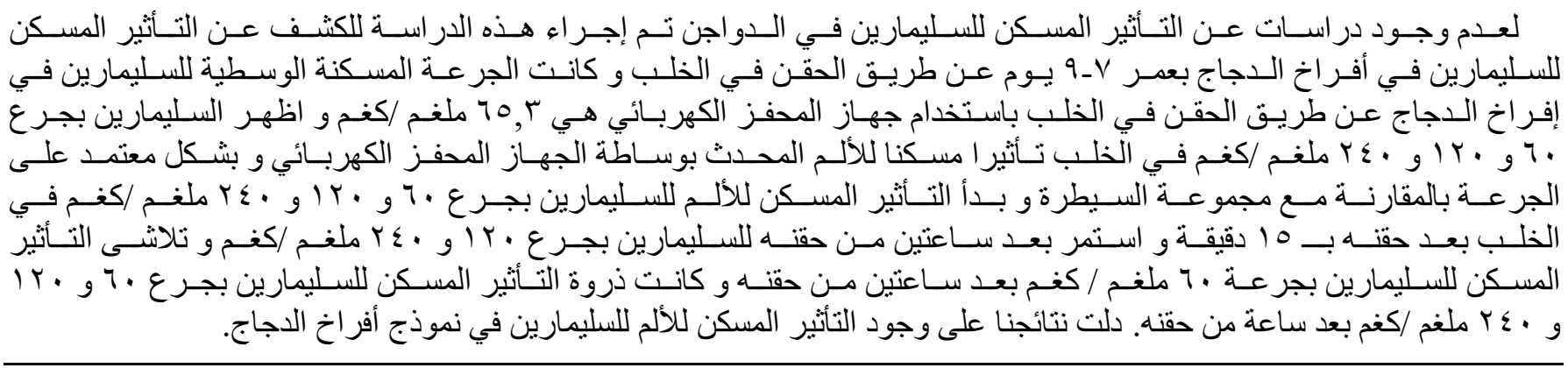

\section{Introduction}

Phytomedicine, also named Herbal medicine, refers to the use of seeds, berries, roots, leaves, bark, or flowers for medical purposes. Silymarin is got from Silybum marianum (milk thistle), a palatable plant that has been used medicinally for centuries as an herbal medicine for the treatment of liver disease (1). Silymarin is the active extract of seeds and fruits of the milk thistle (Silybum marianum) and contains the flavonolignans isomers called silybin, isosilybin, silydianin, and silychristin. It has almost no known side effects (1). Silymarin clinically used in the treatment of many of liver disorders like hepatitis, chronic alcoholic liver disease, liver cirrhosis, ischemic injury, and radiation toxicity (2). Silymarin have many pharmacological actions as a free radical scavenger that affects various steps in arachidonic acid cascade via cyclooxygenase and lipoxygenase pathways (3). Besides, 
silymarin modulates immune system through suppression of neutrophil immigration and mast cell immobilization (4). It also inhibits TNF- $\alpha$-induced production of free radicals and lipid peroxidation, and modulates T-cell function $(5,6)$. Increasing the concentrations of the endogenous antioxidant enzymes like glutathione peroxidase, glutathione reductase, superoxide dismutase and catalase $(7,8)$. In addition, it's considered a liver protection for its efficiency to stabilize the cell membranes of hepatocytes, blocking the entry of toxic substances into these cells. Silymarin joins to receptors present on these membranes, inhibiting the binding of toxins in these sites, reducing drug-induced hepatocellular damage $(9,10)$. It also stimulates the synthesis and activity of enzymes responsible for the hepatic biotransformation process, such as glutathione Stransferase $(11,12)$. Due to the adverse effects of available synthetic medications in the long term treatment of painful conditions and inflammation, many studies have tested different plant extracts and their active compounds for antinociceptive and anti-inflammatory activities $(13,14)$. There are no published reports of silymarin on its analgesic profile. Thus, the objective of the present work is to explore the potential of herbal medicine silymarin for its analgesic effects using the electric stimulation method to induce pain in chicks.

\section{Materials and methods}

Day old Ross broiler chicks of both sexes were purchased from a certified local hatchery and they were maintained until the age of 7-9 days when the experiments were done. The chicks were housed in a room with a temperature of $32-35^{\circ} \mathrm{C}$, constant lighting, and wood shavings as floor litter, with free access to drinking water and feed. The commercial powder of silymarin $(175 \mathrm{mg}$, $21^{\mathrm{ST}}$ Century HealthCare, Inc.) was dissolved in warm distilled water to obtain the concentrations needed for injection intraperitonially (i.p.) in a volume of $10 \mathrm{ml} / \mathrm{kg}$ body weight (15). Chicks in the control group were injected i.p. with physiological saline solution at $10 \mathrm{ml} / \mathrm{kg}$. All doses of silymarin were freshly prepared before each experiment. All experiments complied with our institutional regulations addressing animal use, attention and humane care which are based on the guidelines of the National Research Council (16).

\section{Determination of the median effective dose $\left(E D_{50}\right)$ of silymarin for the induction of analgesia in chicks}

The up-and-down method (18) was used to determine separately the individual $\mathrm{ED}_{\mathbf{5 0}}$ of silymarin for the induction of analgesia in chicks. Analgesia was assessed by the increase in pain threshold using an electric stimulator (SRI, Scientific and Research Instruments Ltd, UK) after setting the frequency at $50 \mathrm{~Hz}$, the width at $5 \mathrm{~ms}$ and the pulse amplitude at 10 volts. The electrodes of the stimulator were gently put in the free feather of the upper chest region, wetted with distilled water, under the wing. The response of the chick to pain after electric stimulation was in the form of distress calls and/or resisting with wing flapping $(18,19)$. Each chick was subjected to a minimum voltage that caused aversive pain response before the silymarin injection and then $15 \mathrm{~min}$ after the injection. The increase or decrease in voltage that caused pain response was calculated for each chick. Usually, the latency for positive analgesic response was apparent within $2 \mathrm{~s}$ after the electrical stimulation. The choice of these doses based on preliminary experiments in chicks.

\section{Dose dependent analgesic effect of silymarin in chicks}

Thirty-two chicks were randomly divided into four groups of eight birds each. The chicks were injected with either normal saline solution (control) or with silymarin at 60,120 and $240 \mathrm{mg} / \mathrm{kg}$. The highest dose of silymarin was almost two-fold of the analgesic $\mathrm{ED}_{\mathbf{5 0}}$ of the drug. For each chick, we measured the minimum voltage that caused aversive pain response at $0,15,30,60$ and $120 \mathrm{~min}$ after the injection. The increase in the voltage in each group was assessed statistically to determine the analgesic response of the chicks to silymarin.

\section{Statistical Analysis}

Data were expressed as mean + SEM. Statistical analysis was done by using one-way analysis of variance (ANOVA) followed by Dunnett's test. $\mathrm{P}<0.05$ were considered significant (17).

\section{Results}

Determination of the median effective dose $\left(E D_{50}\right)$ of silymarin for the induction of analgesia in chicks

The $\mathrm{ED}_{50}$ value of silymarin determined by the up-anddown method for the induction of analgesia in the chicks was $65.3 \mathrm{mg} / \mathrm{kg}$, i.p (Table 1).

\section{Dose dependent analgesic effect of silymarin in chicks}

Silymarin produced a dose dependent analgesic effect following its intraperitonially administration; when given to chicks at 60,120 and $240 \mathrm{mg} / \mathrm{kg}$ in comparison with the control group which injected with normal saline only. In the groups with larger doses 120 and $240 \mathrm{mg} / \mathrm{kg}$ the significance of analgesic effect started at $15 \mathrm{~min}$ after injection and lasted over 120 min of injection were as the group with $60 \mathrm{mg} / \mathrm{kg}$ the analgesic effect started at $15 \mathrm{~min}$ after injection and declined after $120 \mathrm{~min}$ of injection. The peak of analgesic effect for 60,120 and $240 \mathrm{mg} / \mathrm{kg}$ were at $60 \mathrm{~min}$ after injection (Figure 1). The observations are given in table 2. 
Table 1: Median effective dose $\left(\mathrm{ED}_{50}\right)$ of silymarin injected intraperitonially for induction of analgesia in 7-9 day-old chicks

\begin{tabular}{lc}
\hline Variable & Analgesia \\
\hline $\mathrm{ED}_{50}(\mathrm{mg} / \mathrm{kg})$ & 65.3 \\
Range of the doses used $(\mathrm{mg} / \mathrm{kg})$ & $60-80-100$ \\
Initial dose $(\mathrm{mg} / \mathrm{kg})$ & 100 \\
Last dose $(\mathrm{mg} / \mathrm{kg})$ & 80 \\
Number of chicks used & 6 (xxoxox) \\
Increase or decrease in the dose $(\mathrm{mg} / \mathrm{kg})$ & 20 \\
Minimum-maximum voltage that caused pain & $6-9$ before silymarin injection \\
\end{tabular}

$\mathrm{X}$ : Positive response of analgesia, O: Negative response of analgesia, The $\mathrm{ED}_{50}$ were determined by the up-and-down method (18).

Table 2: Effect of silymarin $(60,120$ and $240 \mathrm{mg} / \mathrm{kg})$ on electrostimulation in chicks

\begin{tabular}{lcccc}
\hline \multirow{2}{*}{ Groups } & \multicolumn{4}{c}{ The increase in voltage caused pain after } \\
\cline { 2 - 5 } & $15 \mathrm{~min}$ & $30 \mathrm{~min}$ & $60 \mathrm{~min}$ & $120 \mathrm{~min}$ \\
\hline Control & $0.0 \pm 0.26$ & $0.25 \pm 0.25$ & $0.0 \pm 0.33$ & $0.0 \pm 0.28$ \\
Silymarin $60 \mathrm{mg}$ & $1.13 \pm 0.23^{*}$ & $2.13 \pm 0.48^{*}$ & $3.00 \pm 0.27^{*}$ & $0.13 \pm 0.13$ \\
Silymarin $120 \mathrm{mg}$ & $1.75 \pm 0.25^{* \mathrm{a}}$ & $2.38 \pm 0.38^{* \mathrm{a}}$ & $3.38 \pm 0.53^{*}$ & $1.25 \pm 0.37^{*}$ \\
Silymarin $240 \mathrm{mg}$ & $3.62 \pm 0.18^{* \mathrm{a}}$ & $3.75 \pm 0.31^{* \mathrm{a}}$ & $4.38 \pm 0.38^{* \mathrm{a}}$ & $2.13 \pm 0.30^{* \mathrm{ab}}$ \\
\hline
\end{tabular}

$\mathrm{n}=8$, the observations are mean $\pm \mathrm{SEM},{ }^{*} \mathrm{P}<0.05$, as compared to control, a $\mathrm{P}<0.05$, as compared to silymarin at $60 \mathrm{mg} / \mathrm{kg}, \mathrm{b}$ $\mathrm{P}<0.05$, as compared to silymarin at $120 \mathrm{mg} / \mathrm{kg}$.

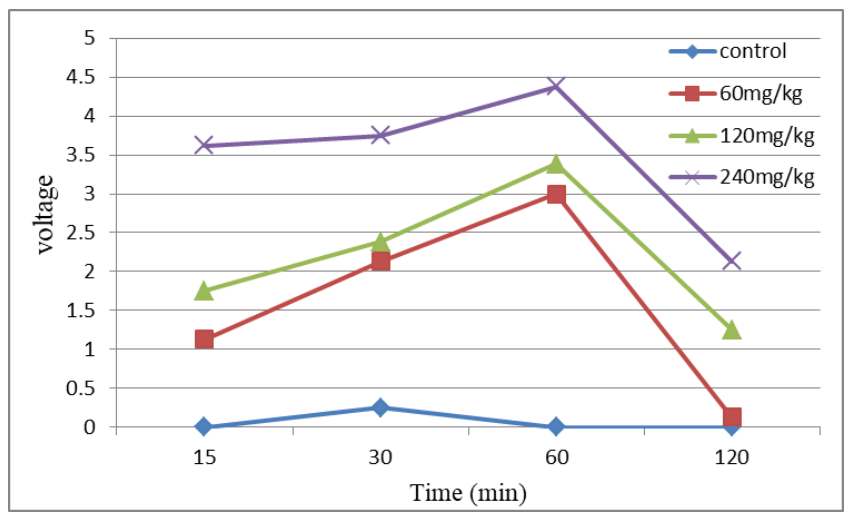

Figure 1: Analgesic effect of silymarin at 0 (control group), 60,120 and $240 \mathrm{mg} / \mathrm{kg}$ i.p. after 15, 30, 60 and $120 \mathrm{~min}$ of injection. Calling of chicks was the indicator for pain sensation after raised the voltage of electrostimulator.

\section{Discussion}

In the present study, silymarin demonstrated a significant $(\mathrm{P}<0.05)$ analgesic activity at different doses. We demonstrated the analgesic effect of silymarin by electric stimulation experimental protocols $(19,20)$. It is very important to study herbal products for assaying their unknown properties, as recently numbers of herbal products are being introduced in the market. In view of this, an attempt to study the silymarin for its analgesic activity in the chicks model. Pain and hyperalgesia are related to diverse clinical cases like inflammatory conditions, cancer, vascular diseases and burns (21). Several studies explored the analgesic effect of silymarin in mice and rats using different techniques for assaying pain and analgesia, different routes of administration and different time for assaying the pain and analgesia (22-25). The $\mathrm{ED}_{50}$ for analgesic effect of silymarin in chicks model was 65.3 $\mathrm{mg} / \mathrm{kg}$ i.p. This dose of silymarin helps us to choose the doses of our study. Analgesic effect of silymarin was clear against control group, changes in the dose and time of silymarin administration may be involved in its analgesic effect, silymarin at $60 \mathrm{mg} / \mathrm{kg}$ showed disappearance of analgesic effect after $120 \mathrm{~min}$ of injection whereas silymarin at 120 and $240 \mathrm{mg} / \mathrm{kg}$ showed persistent analgesic effect over $120 \mathrm{~min}$. However, a similar argument about the analgesic effect in mice and rats was previously demonstrated (22-25). Our finding indicated that the peak of analgesic effect of silymarin was 1hour after intraperitonially injection for all doses of silymarin Figure1. The exact mechanism of action of the silymarin as analgesic drug was unclear, several studies attributed the analgesic effect to the inhibitory effect of Tumor necrosis factor $-\alpha$, Interleukin $1 \beta$, cyclooxygenase 2 and prostaglandin $E_{2}$, these inflammatory mediators suppress by block the mRNA expression of it by silymarin $(5,26)$. Other researchers suggested that the silymarin have antinociceptive effect due to its inhibition of prostaglandins ( $\mathrm{PGE}_{2}$ and prostaglandin $\mathrm{F}_{2}$ ) (pain inducers) (27-30). In 
addition, Moreover, different receptors for neurotransmitters, responsible in the pain transmission, are not the same in these animal models. Therefore, various analgesic activity profiles of different models may be seen.

\section{Conclusion}

Our present study indicates that silymarin has significant analgesic effect on the chicks model thus, it can be concluded that silymarin has analgesic effect which are may be mediated by suppression of prostaglandin synthesis and other autacoid mediated inflammatory response as well as central inhibitory mechanism, which may find a clinical benefit for the control of painful condition in our animal model

\section{Acknowledgement}

This study was supported by the College of Veterinary Medicine, University of Mosul, Mosul, Iraq.

\section{References}

1. Flora K, Hahn M, Rosen H, Benner K. Milk thistle (Silybum marianum) for the therapy of liver disease. J Gastroenterol. 1998;93:139-143. https://doi.org/10.1111/j.1572-0241.1998.00139.x

2. Saller R, Meier R, Brignoli R. The use of silymarin in the treatment of liver https://doi.org/10.2165/00003495-200161140-00003

3. Gupta OP, Sing S, Bani S, Sharma N, Malhotra S, Gupta BD, Banerjee SK, Handa SS. Anti-inflammatory and anti-arthritic activities of silymarin acting through inhibition of 5lipoxygenase. Phyto Med. 2000;7:21-24. https://doi.org/10.1016/S0944-7113(00)80017-3

4. Kang JS, Jeon YJ, Park S-K, Yang KH, Kim HM. Protection against lipopolysaccharide-induced sepsis and inhibition of interleukin- $1 \beta$ and prostaglandin $\mathrm{E}_{2}$ synthesis by silymarin. Biochem Pharmacol. 2004;67:175-181. https://doi.org/10.1016/j.bcp.2003.08.032

5. Manna SK, Mukhopadhyay A, Van NT, Aggarwal BB. Silymarin suppresses TNF-induced activation of NF-kappa B, c-Jun N-terminal kinase, and apoptosis. J Immunol. 1999;163:6800-6809.

6. Nazemian F, Karimi G, Moatamedi M, Charkazi S, Shamsara J, Mohammadpour AH. Effect of silymarin administration on TNF-alpha serum concentration in peritoneal dialysis patients. Phytother Res. 2010;24:1654-1657. https://doi.org/10.1002/ptr.3175

7. Fehér J, Láng I, Nékám K, Müzes G, Deák G. Effect of free radical scavengers on superoxide dismutase (SOD) enzyme in patients with alcoholic cirrhosis. Acta Med Hung. 1988;45:265-276.

8. Pradhan SC, Girish C. Hepatoprotective herbal drug, silymarin from experimental pharmacology to clinical medicine. Indian $\mathrm{J}$ Med Res. 2006;124:491-504.

9. Salamone F, Galvano F, Cappello F, Mangiameli A, Barbagallo I, Li Volti G. Silibinin modulates lipid homeostasis and inhibits nuclear factor kappa B activation in experimental nonalcoholic steatohepatitis. Transl https://doi.org/10.1016/j.trsl.2011.12.003

10. Tuchweber B, Sieck R, Trost W. Prevention of silybin of phalloidininduced acute hepatoxicity. Toxicol Appl Pharmacol. 1979;51:265275.
11. Faulstich H, Jahn W, Wieland T. Silybin inhibition of amatoxin uptake in the perfused rat liver. Arzneimittelforschung. 1980;30:452454.

12. Mateen S, Raina K, Agarwal R. Chemopreventive and anti-cancer efficacy of silibinin against growth and progression of lung cancer. Nut Can. 2013;65 (Suppl 1):3-11. https://doi.org/ $10.1080 / 01635581.2013 .785004$

13. Iranshahi M, Askari M, Sahebkar A, Adjipavlou-Litina D. Evaluation of antioxidant, anti-inflammatory and lipoxygenase inhibitory activities of the prenylated coumarin umbelliprenin. DARU J Pharmaceut Sci. 2009;17:99-103.

14. Monsef HR, Ghobadi A, Iranshahi M, Abdollahi M. Antinociceptive effects of Peganum harmala L. alkaloid extract on mouse formalin test. J Pharm Pharm Sci. 2004;7:65-69.

15. Kamal AA, Rasha RA, Walaa GH, Aziza A. Renoprotective and antioxidant effects of silymarin and propolis on diclofenac sodium induced renal toxicity in rats int. J Pure App Biosci. 2017;5(2):31-42.

16. National Research Council. Guide for the care and use of laboratory animals. $8^{\text {th }}$ ed. Washington: National Academies Press; 2011.

17. Petrie A, Watson P. 1999. Statistics for veterinary and animal science. Oxford: Blackwell Science Ltd.

18. Dixon WJ. Efficient analysis of experimental observations. Ann Rev Pharmacol Toxicol. 980;20:441-462.

19. Mousa YJ. Anesthetic properties of ketamine in chicks stressed with hydrogen peroxide. Vet Med. 2014;59(8):369-375.

20. Mousa YJ, Mohammad FK. The analgesic efficacy of xylazine and dipyrone in hydrogen peroxide-induced oxidative stress in chicks. Iraqi J Vet Sci. 2012;26(2):69-76.

21. Hale ZT, Tuba TA, Gozde E, Meral Y, Feriha E, Goksel S. Silymarin, the antioxidant component of Silybum marianum, protects against burn-induced oxidative skin injury. Burns. 2007;33:908-916. https://doi.org/10.1016/j.burns.2006.10.407

22. Ahmed SS. Antinociceptive effect of silymarin in experimental animals. Al-Kindy Col Med J. 2011;7:2.

23. Jadhav GB, Upasani CD. Analgesic effect of silymarin in experimental induced pain in animal models. J Pharm Res. 2009;2(8):1276-1278.

24. Faezeh VH, Ramin R, Hasan S, Mahmoud H, Kobra S, Gholamreza $\mathrm{K}$. Effects of silymarin on neuropathic pain and formalin induced nociception in mice. Iran J Basic Med Sci. 2015;18(7):715-720.

25. Mohamed MA, Mahmoud SA. Estimation of the novel antipyretic, anti-inflammatory, antinociceptive and antihyperlipidemic effects of silymarin in Albino rats and mice. Asian Pac J Trop Biomed. 2015;5(8):619-623

26. Kang JS, Jeon YJ, Park SK, Yang KH, Kim H M. Protection against lipopolysaccharide-induced sepsis and inhibition of interleukin-1beta and prostaglandin $\mathrm{E}_{2}$ synthesis by silymarin. Biochem Pharmacol. 2004;67(1):175-181. https://doi.org/10.1016/j.bcp.2003.08.032

27. Dongmo AB, Beppe JG, Nole T, Kamanyi A. Analgesic activities of the stem bark extract of Terminalia superba Engl. et Diels (Combretaceae). Pharmacol Online. 2006;2:171-177 .

28. Jadhav GB, Upasani CD. Analgesic effect of silymarin in experimental induced pain in animal model. J Pharm Res. 2009;2(8):1276-1278.

29. Prasanna GS, Ashok P. Antihyperhomocysteinemic and antihyperlipidemic effect of Trichilia connaroides in methionineinduced hyperhomocysteinemic animals. Indian J Pharmacol.2011;43(2):203-206. ｈttps://doi.org/10.4103/02537613.77371

30. Woo SM, Min KJ, Chae IG, Chun KS, Kwon TK. Silymarin suppresses the $\mathrm{PGE}_{2}$-induced cell migration through inhibition of $\mathrm{EP}_{2}$ activation: $G$ protein-dependent PKA-CREB and $G$ proteinindependent Src-STAT3 signal pathways. Mol Carcinog. 2015;54(3):216-28. https://doi.org/10.1002/mc.22092. 